\title{
GAMBARAN PENATALAKSANAAN BAYI BARU LAHIR YANG MENGALAMI ASFIKSIA NEONATORUM DI RUMAH SAKIT UMUM DAERAH DR.H.SOEWONDO KABUPATEN KENDAL
}

\author{
Mimi Ruspita, HenyRosiana \\ 1,2,3UPPKampus Kendal PoltekkesKemenkes Semarang, Indonesia
}

\begin{abstract}
Asphyxia neonatorum is a newborn baby emergency because of breathing difficulties that can continue to cause various complications. Asphyxia is most common in the period immediately after the baby is born. It is estimated that one third of babies who need resuscitation do not show danger signs, therefore very important for midwives to be able to carry out simple and effective neonatal resuscitation. The purpose of this search is to know the description of the management of neonatal asphyxia by type and SOP in RSUD DR. H. Soewondo Kendal. This research is a descriptive study using a survey approach. The method of collecting data by observing using a checklist and SOP checklist for management asphyxia neonatorum which is then processed using Univariate analysis. The results showed that the management of neonatal asphyxia in 42 infants, all (100\%) were resuscitated, 9 infants $(21,4 \%)$ had VTP and 4 infants $(9,5 \%)$ had chest compressions. While of 42 treatments that have been carried out there are actions that are not in accordance with the SOP. The results showed that the management of newborns who had neonatal asphyxia had not been carried out according to the SOP. So it is recommended especially for midwives to have awarness of the importance of managing neonatal asphyxia in accordance with SOP.
\end{abstract}

Keyword :neonatal asphyxia; management; SOP; newborn baby 


\section{PENDAHULUAN}

Salah satu alat untuk menilai keberhasilan program pembangunan kesehatan yang telah dilaksanakan di suatu negara adalah dengan melihat perkembangan angka kematian dari tahun ke tahun. Menurut hasil Survei Demografi dan Kesehatan Indonesia (SDKI) 2017 menunjukkan bahwa angka kematian bayi di Indonesia saat ini adalah 24 per 1.000 kelahiran hidup. Di antara angka ini, 15 per 1.000 kematian terjadi pada masa neonatal atau sejak lahir sampai usia 28 hari. (BPS, BKKBN, Kemkes, ICF, 2017)

AKB Jawa Tengah tercatat 10,41 per 1.000 kelahiran hidup. Pada 2017 sudah turun menjadi 8,93 per 1.000 kelahiran hidup. (Portal Resmi Provinsi Jawa Tengah,2018).Apabila dibandingkan dengan target dalam SDG's global AKN menjadi kurang dari 12 per 1.000 kelahiran hidup pada 2030, maka AKB di Propinsi Jawa Tengah sudah melampaui target. Namun yang menjadi penyeb utama kematian bayi masih menjadi prioritas penanganan, dimana penyebab utama kematian bayi usia $0-6$ hari, $37 \%$ karena gangguan kelainan pernafasan, termasuk asfiksia neonatorum (BPS, BKKBN, Kemkes, ICF, 2017)

Tindakan tenaga kesehatan merupakan suatu upaya preventif yang berkualitas dan seyogyanya terus dipertahankan untuk meminimalkan penyebab dasar kematian yang diakibatkan karena sistem pelayanan kesehatanyang lemah. Menurut data sebelumnya, dari $58 \%$ bayi neonatal yang mengalami gangguan pernapasan, 42\% nya adalah bayi dengan asfiksia lahir yang dapat diintervensi dengan melakukan resusitasi (Sarimawar,2009). Hal yang menjadi tantangan adalah menjaga agar penatalaksanaan asfiksia dapat dilanjutkan dan diterapkan dengan baik. (Dwi,2009).

Berdasarkan studi pendahuluan di RSUD dr. H. Soewondo kendal pada tahun 2017 diperoleh data total jumlah kelahiran sebanyak 1.237 dengan jumlah kematian perinatal 140 kasus atau sekitar $11,3 \%$ dari seluruh kelahiran hidup. Dari seluruh kelahiran tersebut, yang mengalami asfiksia sebanyak 672 kasus atau sekitar $54,3 \%$. Sedangkan kematian perinatal yang disebabkan asfiksia neonatorum sebanyak 35 kasus atau sekitar $5,2 \%$ dari seluruh bayi baru lahir yang mengalami asfiksia.

Sehubungandenganmasihbanyaknyaka susasfiksianeonatorum yang menjadipenyebabkematianbayi, makasangatpentingupayapenatalaksanaa nterhadapbayiasfiksia yang dilakukandengantepatdansesuaidenganpr osedurtetap yang telahditetapkan di semuafasilitaskesehatantermasukRumah Sakit.Begitu pula dengankepatuhantenagakesehatandalam melakukanpenatalaksanaanterhadapbayia sfiksia yang tepatmenjadiupayapreventifterjadinyakem atianbayi. 


\section{METODOLOGI PENELITIAN}

Penelitianinimenggunakanmetode

deskriptif

denganpendekatanSurvey.Populasinyaad

alahsemuabayibarulahir yang

mengalamiasfiksianeonatorum di RSUD

dr.H.Soewondo Kendal Maret - April 2018

yang berjumlah 42

bayi.Pengambilansampeldalampenelitiani

nimenggunakanaccidental

sampling,yaitusemuabayibarulahir yang

mengalamiasfiksianeonatorum di RSUD

dr.H.Soewondo Kendal padabulanMaret -

April 2018 yang berjumlah 42bayibarulahir yang

mengalamiasfiksianeonatorumatauseluruh jumlahpopulasi.Untukmendapatkan data jenispenatalaksanaanasfiksianeonatorump engamattinggalmemberitanda check $(\sqrt{ })$ padakolom "JenisPenatalaksanaan" yang dilakukan,

dengansyaratjenispenatalaksanaandilakuk andariawalsecarabertahap.

Sedangkanuntukmendapatkandata prosedurpenatalaksanaanasfiksianeonator umdisesuaikandengan SOP, pengamattinggalmemberikantanda check $(\sqrt{ })$ padakolom "Ya" apabilasesuaidengan SOP dantanda check $(\sqrt{ })$ padakolom "Tidak"

apabilaprosedurpenatalaksanaantidakdila

kukansesuai

SOP.

Kemudiandarijawabantersebutdijumlahdan apabilajawabansemuayamakapenatalaksa naandikategorikansesuai.Apabilaterdapat jawabantidakmakadikategorikantidaksesu ai.Analisa data dalampenelitianinimenggunakananalisaUn ivariate.Data yang sudah terkumpul disederhanakan dengan pengelompokan data sesuai variabel. Didapatkan perolehan jumlah jawaban kemudian di hitung besarnya persentase dengan menggunakan rumus Persentase yaitu:

$$
X=\frac{f}{n} \times 100 \%
$$

Keterangan :

$X=$ jumlah persen

$f=$ frekuensi hasil pencapaian.

$n=$ total seluruh populasi

\section{HASIL PENELITIAN DAN BAHASAN}

1. Penatalaksanaan Asfiksia Neonatorum Berdasarkan Jenis

Dari hasil penelitian yang dilakukan dari 42 bayi baru lahir yang mengalami asfiksia neonatorum di RSUD dr.H.Soewondo Kendal menunjukkan bahwa semuanya dilakukan penatalaksanaan resusitasi, 9,5\% yang dilakukan kompresi dada,21,4\% yang dilakukan penatalaksanaan VTP dansisanya $\quad 69,1 \%$ dilakukanpenatalaksanaanlangkahawal.

2. Penatalaksanaan Asfiksia Neonatorum Berdasarkan SOP

Hasil penelitian terhadap penatalaksanaan bayi baru lahir yang mengalami asfiksia neonatorum berdasarkan SOP yang ada di RSUD 
DR.H.Soewondo Kendal menunjukkan bahwa semua penatalaksaan terhadap 42 bayi dengan asfiksia neonatorum tidak sesuai dengan SOP.

SOP penatalaksanaan asfiksia neonatorum di RSUD DR.H.Soewondo Kendal yaitu prosedur pertama yang dilakukan dengan langkah awal resusitasi yaitu HAIKAL, Bila bayi tidak bernafas atau megap-megap atau tetap sianosis setelah diberi oksigen 100\%, lakukan segera VTP. Bila tidak bernafas atau megap-megap atau frekuensi jantung $<100-60 \mathrm{x} /$ menit atau sianosis teruskan VTP, melanjutkan penatalaksanaan dengan Kompresi Dada. Bila frekuensi jantung $\leq 60 \mathrm{kali} / \mathrm{menit}$, berikan pengobatan dengan epinefrin, melalui pipa ET (lebih diutamakan) atau jalur intra vena. Kemudian segera lakukan kompresi dada dan VTP dengan koordinasi yang baik selama 30 detik dan nilai keadaan bayi. Keputusan untuk menghentikan resusitasi bila setelah 15 menit melakukan Resusitasi awal,VTP dan Kompresi dada dengan benar, tetap tidak ada denyut jantung.

Hasil penelitian yang dilakukan untuk penatalaksanaan Resusitasi terdapat tindakan yang tidak sesuai SOP yaitu tidak mengaktifkan alat pemancar panas, tidak meletakkan bayi di bawah pemancar panas dan ada yang tidak memposisikan bayi setengah menengadah. Tidak sesuai SOP dalam tindakan resusitasi untuk mengaktifkan alat pemancar panas dan meletakkan bayi di bawah alat pemancar panas disebabkan kurangnya fasilitas alat pemancar panas untuk menghangatkan bayi. Sehingga penatalaksanaan resusitasi untuk menghangatkan bayi dilakukan dengan alternatif lain untuk mencegah kehilangan panas yaitudengan menyelimuti tubuh bayi dengan kain yang hangat yang sebelumnya mengeringkan bayi tanpa membersihkan verniks.Sedangkan tidak dilakukan tindakan memposisikan kepala bayi sedikitmenengadahada yang melakukandanada yang tidak, padahalpentingmengatur posisi kepala bayi sedikitmenengadah untuk membebaskanjalannafassehinggamemper mudah melakukan penghisapan lendir dan menghindari terjadinyaaspirasi

Penatalaksanaan

VentilasiTekananPositifjuga masih terdapat tindakan yang dilakukan tidak sesuai SOP yaitu tidak meletakkan bayi dibawah pemancar panas. Penyebabnya sama seperti pada penatalaksanaan resusitasi dimana tidak terdapat alat pemancar panas, sehingga menghangatkan bayidiganticaradengan menyelimuti dan mengeringkan bayiuntuk mencegah terjadinyahipotermi pada bayi. Sedangkan tidak menguji balon sungkupsaatakandilakukan

VTPkarenapetugasmerasa bahwa upaya VTP

sudahseringdillakukansehinggatidakperlud iujicobalagi. Padahal persiapan menguji balon sungkup bertujuanuntuk 
memastikan oksigen masukke pernafasan bayi.

Penatalaksanaan asfiksia neonatorum kompresi dada, yang tidak sesuai SOP sama seperti penanganan sebelumnya yaitu tidak meletakkan bayi dibawah pemancar panassehinggadilakukan dengan alternatif lain untuk mencegah kehilangan panas yaitudengan menyelimuti tubuh bayi dengan kain yang hangat yang sebelumnya mengeringkan bayi tanpa membersihkan verniks. Sedangkan tidak sesuai prosedur dikarenakan kurangnya fasilitas pendukung untukpenatalaksanaan dan kurangnya

kepatuhansebagiantenagatenaga

kesehatan untuk melakukan penatalaksanaan asfiksia neonatorum yang benar. Padahal tindakan tenaga kesehatan merupakan suatu upaya preventif untuk meminimalkan penyebab dasar kematian bayi baru lahir.

\section{KESIMPULAN}

Hasil penelitian tentang "Gambaran Penatalaksanaan Bayi Baru Lahir yang Mengalami Asfiksia Neonatorum di RSUD DR.H.Soewondo Kabupaten Kendal" dapat diambil kesimpulan sebagai barikut :

1. Penatalaksanaan resusitasi dilakukan tindakan sebagian besarr dilakukan pada tahap awal tapa inkubasi endotrakeal dan pemberian obat

2. tindakan VTP dilakuan pada sebagain bayi
3. sebagian kecil bayi dilakukan Kompresi dada

4. Penatalaksanaan asfiksia neonatorum semuanya belum sesuai SOP terutama tidak meletakan bayi dibawah pemancar panas tetapi dengan menyelimuti bayi dengan kain hangat .

Disarankan untuk tenaga kesehatan yang memberikan pelayanan untuk melaksanakan tindakan sesuai sop yang ada serta ntuk peneli selanjutnya dapat dilakukan penelitian tentag efektifitas menjaga kehangatan bayi baru lahir untuk dalam penanganan asfiksia.

\section{DAFTAR PUSTAKA}

Arikunto,Suharsimi (2010), Prosedur Penelitian : Suatu Pendekatan Praktik, Jakarta : Rineka Cipta

BadanPusatStatistik, BadanKependudukandanKeluargaB erencanaNasional,

KementrianKesehatan, ICF (2017), SurveiDemografidanKesehat an Indonesia

Dwi HT , Sarimawar D (2009), Aspek kehamilan dan persalinan pada kematian neonatal akibat asfiksia lahir sebelum dan setelah interval manajemen asfiksia di Kabupaten Cirebon, JurnalEkologiKesehatan, Vol.8 No.3

Hidayat, A, Aziz Alimul (2011), Metode Penelitian Kebidanan dan Teknis Analisa Data, Jakarta : Salemba Medika

Jitowiyono dan Kristiyanasri (2010), Asuhan Keperawatan Neonatus dan Anak, Yogjakarta : Nuha Medika 
Kosim, dkk (2008), Buku Ajar Neonatologi, Jakarta: IDAI

Manuaba IBG, Manuaba IAC, ManuabalBGF (2009), Buku Ajar Patologi Obstetri, Jakarta: EGC

Manuaba IBG, Manuaba IAC, ManuabalBGF (2007), Pengantar Kuliah Obstetri, Jakarta: EGC

Mayang, Indah, EP (2012), Hubungan kala I dan kala II lama persalinan dengan kejadian asfiksia neonatorum di RSUD Prof.Margono Soekarjo, Purwokerto : Universitas Muhammadiyah Purwokerto

Meisa P, Sjarif HE(2012), Stabilitasi neonatus pasca tindakan resusitasi: Bandung: Fakultas kedokteran Universitas Padjajaran

Maryunani, Anik dan Nurhayati(2009), Asuhan Kegawatdaruratan dan Penyulit Pada Neonatus, Jakarta: Trans Info Media

Notoatmodjo Soekidjo (2010), Metode Penelitian Kesehatan, Jakarta: Rineka Cipta

Portal ResmiProvinsiJawa Tengah, Penurunan AKI di Jatenglampaui Target SDG's, https://jatengprov.go.id/publik/penur unan-aki-di-jateng-lampaui-targetsdgs/

Rustam Mochtar (2011), Sinopsis Obstetri. Jakarta:EGC

Sondakh, Jenny, JS (2013), Asuhan kebidanan persalinan dan bayi baru lahir, Jawa Timur: Erlangga

Sugiono (2015), Statistika Untuk Penelitian, Bandung: Alfabeta

Prawirohardjo, Sarwono (2016), IImu Kebidanan, Jakarta: Bina Pustaka
Siswanto,dkk (2014), Metodologi Penelitian Kesehatan dan Kedokteran, Yogjakarta: Bursa IImu 